\title{
BIRC5 Expression Is Regulated in Uterine Epithelium during the Estrous Cycle
}

\author{
Minha Cho ${ }^{1,+}$, Ok-Hee Lee ${ }^{2,+}$, Eun Mi Chang ${ }^{1,+}{ }^{+}$, Sujin Lee ${ }^{2}$, Sohyeon Moon ${ }^{3}$, Jihyun Lee ${ }^{3}$, \\ Haeun Park ${ }^{3}$, Keun-Hong Park ${ }^{2}$, Chankyu Park ${ }^{3}$, Kwonho Hong ${ }^{3}$ and Youngsok Choi ${ }^{3, *(D)}$ \\ 1 Fertility Center of Cha Gangnam Medical Center, Seoul 06135, Korea; mhcho@chauniv.ac.kr (M.C.); \\ emchang@cha.ac.kr (E.M.C.) \\ 2 Department of Biomedical Science, CHA University, Gyeonggi-do 13488, Korea; \\ okhlee@chamc.co.kr (O.-H.L.); sj091895@naver.com (S.L.); pkh0410@cha.ac.kr (K.-H.P.) \\ 3 Department of Stem Cell and Regenerative Biotechnology, Konkuk University, Seoul 05029, Korea; \\ 1004sh.moon@gmail.com (S.M.); lsw46340@naver.com (J.L.); phe325@naver.com (H.P.); \\ chankyu@konkuk.ac.kr (C.P.); hongk@konkuk.ac.kr (K.H.) \\ * Correspondence: choiys3969@konkuk.ac.kr; Tel.: +82-2-450-3969 \\ + Authors contributed equally.
}

Received: 30 January 2020; Accepted: 4 March 2020; Published: 6 March 2020

\begin{abstract}
Baculoviral inhibitor of apoptosis repeat-containing 5 (Birc5), also known as survivin, is a member of the inhibitor of apoptosis (IAP) family of proteins and regulates the size of tissues through cell division control. The uterus is the most dynamically sized organ among tissues during the estrous cycle. Although Birc5 is expressed in some terminally differentiated cells, the regulation of its expression in the uterus remains unknown. We investigated the regulation of Birc5 expression in the mouse uterus. RT-PCR analysis showed that Birc5 was expressed in various tissues, including the uterus; the expression level of Birc5 was significantly higher at the diestrus stage. Immunohistochemistry and Western blotting analysis revealed that Birc5 was more active in luminal and glandular epithelium than in endometrial stroma. In ovariectomized mice, Birc5 expression in the uterus was gradually increased by estrogen treatment; however, progesterone injection decreased its expression. Estrogen-induced Birc5 expression was blocked by treatment with estrogen receptor antagonist, ICI 182, 780 and progesterone-reduced Birc5 expression was inhibited by the progesterone receptor antagonist RU486. These results suggest that Birc5 expression is dynamically regulated by a combination of estrogen and progesterone via their receptor-mediated signaling.
\end{abstract}

Keywords: Birc5; uterus; estrogen; progesterone

\section{Introduction}

The uterus is a female reproductive organ that plays an important role in several pregnancy processes such fertilization, implantation, and embryonic development [1]. The endometrium of the uterus is periodically regulated according to the estrous cycle. In humans, the menstrual cycle has an interval of $\approx 28-30$ days. It corresponds to the estrous cycle of 4-5 days in the rodents (reviewed in [2]). The estrous cycle consists of four stages viz. diestrus, proestrus, estrus, and metestrus. The precise regulation of the estrous cycle within $\approx 4-5$ days is very important for a successful pregnancy. The uterine endometrium is dynamically regulated by the ovarian sex hormones estrogen and progesterone. The endometrium undergoes proliferation, differentiation, and shedding (humans and primates) or apoptosis (rodent) in response to hormones during the cycle [2]. 
Baculoviral inhibitor of apoptosis repeat-containing 5, (Birc5, also known as survivin) is an inhibitor of apoptosis (IAP). Birc5 was originally identified and characterized in human cancers [3]. Birc5 was highly expressed in various cancers such as lung cancer, ovarian cancer, breast cancer, brain tumor, colon cancer, pancreatic cancer, osteosarcoma, and cervical cancer (reviewed in [4]). It was used as a prognostic or survival marker in cancer patients. Birc5 acts as inhibitor of apoptotic processes by repressing caspase activity via binding to caspase- 3 and -7 in cancer cells, leading to the survival of cancer cells during tumorigenesis [5].

Recently, many studies o Bir5 expression in various tissue have been reported [4]. The expression of Birc5 has been detected in various normal tissues such as the liver [6], arterial muscle [7], stomach [8], brain [9], ovary [10], testes [11-13], and uterus [1], though at lower levels than in cancers. Birc5 has various functions in cellular processes such as differentiation and proliferation of stem cells and progenitor cells and its deficiency results in embryonic lethality at early stage of embryogenesis, viz. at embryonic day E4.5 [14]. This implies that Birc5 plays a crucial role in cell differentiation and proliferation. In fact, T cell-specific Birc5-knocked-out mice showed that it plays a role in $\mathrm{T}$ cell development and differentiation $[15,16]$. Further, Birc5 is involved in regulating proliferation of hematopoietic stem cells [17] and mesenchymal stromal cells [18]. Moreover, Birc5 expression is regulated by various factors including p53 [19], PTEN [20], SIRT1 [21], HDAC2, and HDAC5 [22].

Almost 20 years ago, Konno and colleagues showed Birc5 expression in normal uterus for the first time [1]; there was no further report in this regard about the uterus until recently. A recent study demonstrated that Birc5 is aberrantly expressed in patients with endometrial hyperplasia [23]. They reported that Birc5 is highly detected in the endometrium of patients with endometrial hyperplasia. Endometrial hyperplasia is caused by abnormally excessive proliferation of endometrial cells in the uterus, which is related to high estrogen level and low progesterone level. However, the regulatory relationship between Birc5 expression and hormones in the normal uterus remains unknown. Therefore, we investigated whether Birc5 is expressed and regulated by hormones in mouse uterus.

\section{Materials and Methods}

\subsection{Animals}

All animal studies were performed using 6-7-week-old ICR mice provided by KOATECH (Pyeongtaek, Korea). Mice were housed under controlled temperature and light conditions with lights on for $12 \mathrm{~h}$ daily and fed ad libitum. Animal care and experimental procedures complied with the Guide for the Care and Use of Laboratory Animals and were approved by the Institutional Animal Care and Use Committee (IACUC) of CHA University.

\subsection{Estrous Cycle and Uterus Sampling}

The stages of estrous cycle were determined by a vaginal smear as described in previous studies [24-26]. Approximately $0.2 \mathrm{~mL}$ of Dulbecco's phosphate buffered saline (DPBS) was drawn into the pipette tip. The tip of the pipette was pushed gently into the entrance of the vagina at a depth of 2-5 mm, and the fluid was flushed into the vagina and then backed up into the pipette; this was repeated two to three times. The collected DPBS was dropped onto a glass slide and dried. Cell staining was carried out by hematoxylin and eosin. After incubating the cells in $50 \%, 75 \%$, and $90 \%$ ethanol for $5 \mathrm{~min}$ each, they were stained with hematoxylin (Vector Laboratory, USA). The slides were washed in tap water for $3 \mathrm{~min}$ and soaked in eosin Y (Sigma-Aldrich, St. Louis, MO, USA) for $10 \mathrm{~min}$. After the eosin treatment, the dyed slides were in turn dipped in $90 \%$ ethanol and then $100 \%$ ethanol for $5 \mathrm{~min}$. After a short incubation in xylene, the slides were covered with cover slips using Permount mounting medium (Thermo Fisher Scientific, Waltham, MA, USA). The staining was observed with a microscope and the stage of the estrous cycles was determined by vaginal smear cytology [27]. Once the estrous cycle was correctly identified, the uterus was isolated. Half of the uterus was processed for RNA and protein extraction and the other half was used for paraffin block. 


\subsection{Ovariectomy and Hormone Treatments}

To examine the effects of hormones on Birc5 expression in the uterus, 7-week-old ICR mice were ovariectomized (OVX). After a stabilization period of 2 weeks, the ovariectomized mice were subcutaneously injected with $\mathrm{E}_{2}(200 \mathrm{ng} /$ mouse, Sigma-Aldrich, St. Louis, MO, USA) and/or $\mathrm{P}_{4}(2 \mathrm{mg} /$ mouse, Sigma-Aldrich, St. Louis, MO, USA). Mice were sacrificed by cervical dislocation and uteri were collected at $0,3,6$, and $24 \mathrm{~h}$ after $\mathrm{E}_{2}$ or/and $\mathrm{P}_{4}$ treatment. To investigate whether the expression of Birc5 in uterus is dependent on $\mathrm{E}_{2}$ or/and $\mathrm{P}_{4}, \mathrm{OVX}$ mice were injected with an ER antagonist, ICI 182,780 (500 $\mathrm{\mu g} / \mathrm{mouse,} \mathrm{Sigma-Aldrich,} \mathrm{St.} \mathrm{Louis,} \mathrm{MO,} \mathrm{USA)} \mathrm{or} \mathrm{PR} \mathrm{antagonist,}$ RU486 (1 mg/mouse) 30 min before $\mathrm{E}_{2}$ or $\mathrm{P}_{4}$ injection. Sesame oil (100 $\mu \mathrm{L} / \mathrm{mouse}$, Sigma-Aldrich, St. Louis, MO, USA) was used for the control mice.

\subsection{RNA Preparation, Reverse Transcription PCR (RT-PCR), and Quantitative Real-Time PCR ( $q R T-P C R$ )}

The tissues isolated from the mice were stored in RNA later solution (Sigma-Aldrich, St. Louis, $\mathrm{MO}$, USA) overnight at $4{ }^{\circ} \mathrm{C}$. After removing RNA later solution, the tissue was homogenized in Trizol reagent (Invitrogen, Waltham, MA, USA) using a homogenizer and then purified with chloroform (Sigma-Aldrich, St. Louis, MO, USA). Total RNA $(1 \mu \mathrm{g})$ was reverse transcribed using SensiFast ${ }^{\mathrm{TM}}$ cDNA Synthesis Kit (Bioline, London, UK) according to the manufacturer's protocol. The product was used for reverse transcription PCR (RT-PCR) and quantitative real-time PCR (qRT-PCR) analyses. RT-PCRs were carried out using C1000 Thermal Cycler (Bio-Rad, Hercules, CA, USA). PCR conditions and size of gene-specific primers are shown as Supplementary Table S1. The PCR products stained with Loading Star (Dyne Bio, Seoul, Korea) were analyzed by gel electrophoresis on $2 \%$ agarose gel using Chemidoc ${ }^{\mathrm{TM}}$ XRS+ system (Bio-Rad, Hercules, CA, USA). Quantitative RT-PCR (qRT-PCR) was performed by the CFX96 Touch (Bio-Rad, Hercules, CA, USA) using iQ $^{\text {TM }}$ SYBR Green Super Mix (Bio-Rad, Hercules, CA, USA). qRT-PCR conditions were as follows: 40 cycles of denaturation at 95 ${ }^{\circ} \mathrm{C}$ for $15 \mathrm{~s}$, annealing at $63^{\circ} \mathrm{C}$ for $15 \mathrm{~s}$, and extension at $72{ }^{\circ} \mathrm{C}$ for $20 \mathrm{~s}$ followed by $10 \mathrm{~min}$ at $72{ }^{\circ} \mathrm{C}$, $10 \mathrm{~s}$ at $95^{\circ} \mathrm{C}$, and $5 \mathrm{~s}$ at $65^{\circ} \mathrm{C}$. To quantify the level of gene expression, the cycle threshold $\left(\mathrm{C}_{\mathrm{T}}\right)$ value was calculated. The $C_{T}$ value for each gene was determined in the linear phase of the amplification and normalized to the $C_{T}$ value of either ribosomal protein L-7 (Rpl7) or Gapdh to obtain the $\Delta \Delta C_{T}$. The $2^{-\Delta \Delta C T}$ method was used for obtaining the fold change of each gene [28].

\subsection{Immunohistochemistry}

Uteri collected from mice were fixed for 1 week in $4 \%$ paraformaldehyde (PFA) at $4{ }^{\circ} \mathrm{C}$ in a paraffin block. The embedded uteri were sectioned at $5 \mu \mathrm{m}$ thickness using a paraffin microtome (Macroteck, Ilsan-si, Korea) and put on adhesion microscope slides (Paul Marienfeld, Lauda-Konigshofen, Germany). Sectioned uteri on the slide were deparaffinized twice in xylene (Duksan, Seoul, Korea) for $7 \mathrm{~min}$ and rehydrated by immersing once each in 100\% ethanol (DaeJung, Seoul, Korea), $90 \%$ ethanol, $75 \%$ ethanol, and $50 \%$ ethanol for $5 \mathrm{~min}$, followed by washing the slides once for $5 \mathrm{~min}$ under tap water. Slides were treated with $3 \%$ hydrogen peroxide for $10 \mathrm{~min}$ to block endogenous peroxide. Deparaffinized slides were boiled in antigen retrieval buffer (10 mM sodium citrate, $0.05 \%$ Tween $20, \mathrm{pH} 6.0)$, cooled at room temperature (RT) for $1 \mathrm{~h}$, and then washed in tap water for $5 \mathrm{~min}$ followed by three washes using phosphate buffered saline containing 0.05\% Tween-20 (PBS-T). After removing PBS-T around tissue section using $3 \mathrm{M}$ paper, a hydrophobic barrier was drawn with ImmEdge hydrophobic pen (Vector Laboratories, USA) on the periphery of the tissue. Sections were blocked with PBS-T containing $4 \%$ bovine serum albumin (BSA) and 5\% normal goat serum (Vector Laboratories, USA) for $1 \mathrm{~h}$ at RT in a humidified chamber. Blocking sections were incubated with anti-survivin mouse monoclonal IgG (1:500 dilution, NB500-238, Novus Biologicals, Centennial, CO, USA) in PBS-T with $4 \%$ BSA at $4{ }^{\circ} \mathrm{C}$ overnight. Slides were washed with PBS-T three times and subsequently were treated with secondary antibody viz. anti-mouse antibody conjugated with HRP (1:200 dilution, G21040, Sigma-Aldrich, St. Louis, MO, USA) for $1 \mathrm{~h}$ at RT. Normal mouse IgG was used as a negative control. Peroxide signals 
were developed using DAB substrate kit (SK-4100, Vector Labs, Burlingame, CA, USA) according to the manufacturer's instruction. After washing, the slides were counter-stained with hematoxylin, washed in tap water, and dehydrated in 50\% ethanol, 75\% ethanol, 90\% ethanol, 100\% ethanol for 5 min each followed by two washes in xylene for $7 \mathrm{~min}$ each. IHC sections were mounted on cover slips with Permount Mounting Medium (StatLab, Lodi, CA, USA). Images were captured and analyzed by Primo Star (Zeiss, Oberkochen, Germany).

\subsection{Western Blotting}

Uteri from adult mice were collected and frozen in liquid nitrogen. The samples were added to $600 \mu \mathrm{L}$ RIPA lysis buffer containing protease inhibition cocktail and grounded using a homogenizer (VWR International, Radnor, PA, USA) with vortexing every $10 \mathrm{~min}$ while being placed on ice for $30 \mathrm{~min}$. After the incubation, the samples were centrifuged at $13,000 \mathrm{rpm}$ for $30 \mathrm{~min}$ at $4{ }^{\circ} \mathrm{C}$ and the supernatant containing proteins was collected and stored at $-80^{\circ} \mathrm{C}$. Equal amounts of protein samples $(10 \sim 20 \mu \mathrm{g})$ were separated by sodium dodecyl sulphate-polyacrylamide gel electrophoresis (SDS-PAGE) using a 10\%-12\% running gel and then transferred to polyvinylidene difluoride (PVDF) membranes (Bio-Rad, Hercules, CA, USA) for $1 \mathrm{~h}$ and $10 \mathrm{~min}$. Membranes were washed in Tris-buffered saline containing 0.05\% Tween-20 (TBS-T), blocked in ProNA ${ }^{\mathrm{TM}}$ phospho-block solution (TransLab, Dajeon-si, Korea) for $1 \mathrm{~h}$ at RT, and incubated with anti-survivin mouse monoclonal IgG (1:1000 dilution, NB500-238, Novus, Centennial, CO, USA) overnight at $4{ }^{\circ} \mathrm{C}$. After washing three times in TBS-T, the blots were incubated with HRP-conjugated goat anti-mouse antibody (1:5000 dilution, sc2005, Santa Cruz Biotechnology Inc., Dalls, TX, USA) in ProNA ${ }^{\mathrm{TM}}$ phospho-block solution for $1 \mathrm{~h}$ at RT. The membranes were washed three times using TBS-T, and subsequently, the blots were developed using ECL ${ }^{\mathrm{TM}}$ Prime Western Blotting Detection Reagent (GE Healthcare, Chicago, IL USA). To check whether the same amount of protein was loaded for each sample, anti-GAPDH antibody (1:2000 dilution, 14C10, Cell signaling technology, Danvers, MA, USA) was used as a loading control. The relative expression of the protein bands was quantified by Image Lab program.

\subsection{Statistical Analysis}

The experimental data were reported as mean \pm standard error of mean $( \pm \mathrm{SEM})$. The results were analyzed by one-way ANOVA for statistical evaluation. A $p$-value of less than 0.05 was considered as statistically significant.

\section{Results}

\subsection{Expression of Birc5 in the Mouse Uterus}

In order to confirm the expression of Birc5 mRNA, we performed RT-PCR analysis using total RNAs, which were extracted from various tissues in the mouse (Figure 1a,b). As shown in Figure 1, Birc5 expression was barely detected in the rest of the tissues including the kidney, liver, heart, brain, and lung (Figure 1a). These results are almost consistent with those from the previous studies indicating that Birc5 expression is detected in normal tissues such as the liver [6], stomach [8], brain [9], ovary [10], and testes [11-13]. However, Birc5 transcripts were detected in high quantities in several tissues including the small intestine, stomach, spleen, ovary, and uterus in the female mice (Figure 1b). After confirming the expression of Birc5 mRNA in the mouse uterus, we examined the expression pattern of Birc5 during the estrous cycle. Vaginal smear assay was used to distinguish each stage of the estrous cycle viz. diestrus, proestrus, estrus, and metestrus (Figure 1c). The results of RT-PCR and qRT-PCR showed a cyclic change in Birc5 expression during the estrous cycle (Figure 1d,e). Birc5 expression level was the highest in diestrus stage and then reduced in the rest of the cycle including in the proestrus, estrus, and metestrus stages (Figure 1e). 
(a)

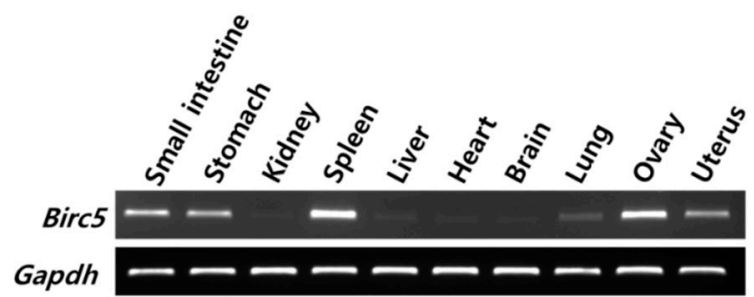

(b)

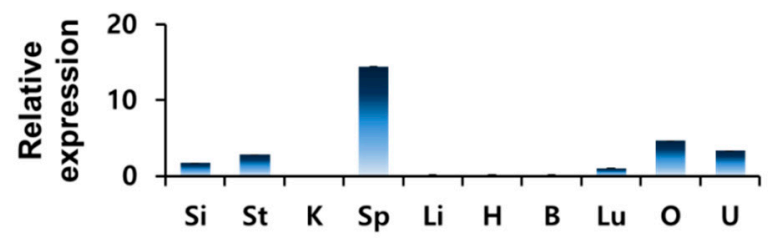

(c)

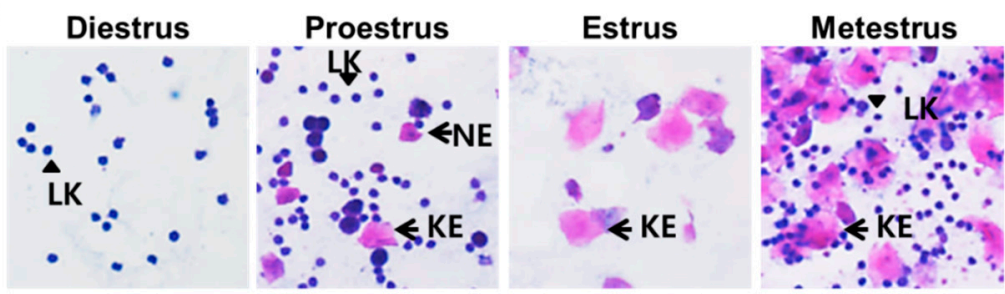

(d)

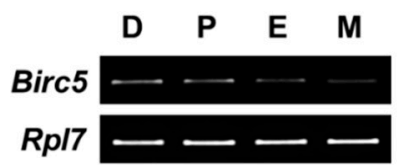

(e)

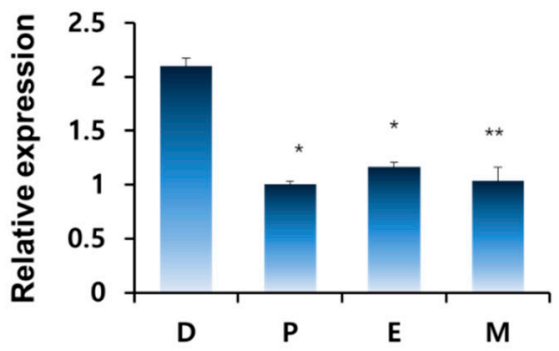

Figure 1. Baculoviral inhibitor of apoptosis repeat-containing 5 (Birc5) expression in mouse tissues. (a) RT-PCR analysis of Birc5 mRNA in the small intestine, stomach, kidney, spleen, liver, heart, brain, lung, ovary, and uterus using total RNA extracted from a 6-week-old female mouse $(n=4)$. Gapdh transcript was used as an internal control. (b) Quantitation of the relative mRNA expression of Birc5 in mouse tissues: Si, small intestine; St, stomach; K, kidney; Sp, spleen; Li, liver; H, heart; B, brain; $\mathrm{Lu}$, lung; $\mathrm{O}$, ovary; $\mathrm{U}$, uterus. The criterion of relative expression change was based on the value at small intestine. (c) Vaginal smear assay to classify the estrous cycle: NE, nucleated epithelial cell; LK, leukocyte; KE, keratinized epithelial cell. (d) RT-PCR results of Birc5 expression in mouse uterus at different estrous stages $(n=4)$ confirmed by vaginal smear assay. $\mathrm{D}$, diestrus; $\mathrm{P}$, proestrus; E, estrus; M, metestrus. (e) Quantitation of the relative mRNA expression of Birc5 in mouse uterus. The criterion of relative expression change was based on the value at metestrus stage of the estrous cycle. Expression levels were normalized against Rpl7 mRNA. D, diestrus; P, proestrus; E, estrus; $\mathrm{M}$, metestrus. ${ }^{*} p$-value $<0.05,{ }^{* *} p$-value $<0.01$.

\subsection{Localization and Expression Level of BIRC5 Protein in Mouse Uterus during the Estrous Cycle}

To investigate the localization and expression of BIRC protein in the mouse uterus, immunohistochemistry (IHC) was performed using mouse monoclonal BIRC5 antibody in the uterus. IHC results showed that BIRC5 was present in all layers of the endometrium (viz. luminal epithelium (LE), glandular epithelium (GE), stroma) (Figure 2a). Interestingly, strong staining was observed in the luminal epithelium and glandular epithelium compared to that in the endometrial stroma. Western blotting showed a relatively similar BIRC5 expression level during the estrous cycle (Figure $2 \mathrm{~b}, \mathrm{c}$ ). Results showed that BIRC5 expression was slightly higher in the diestrus stage than that in metestrus (Figure 2c). 
(a)

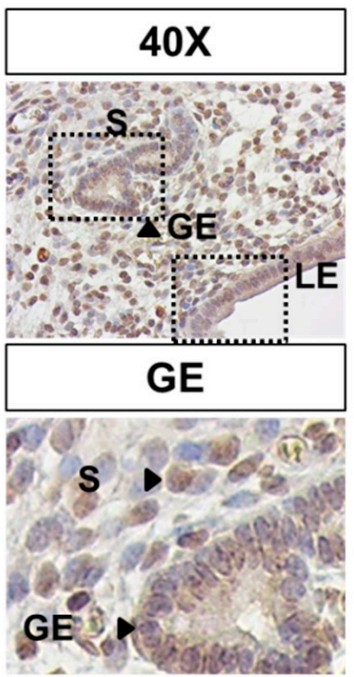

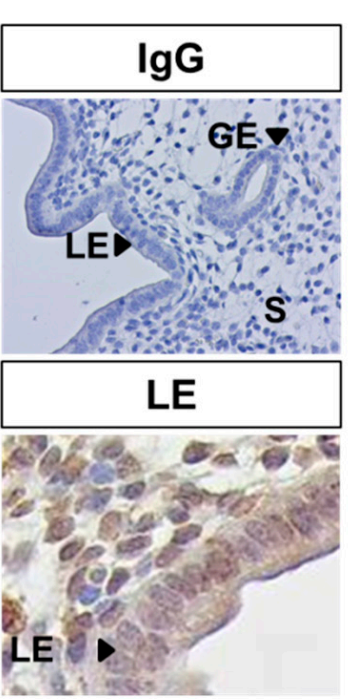

(b)

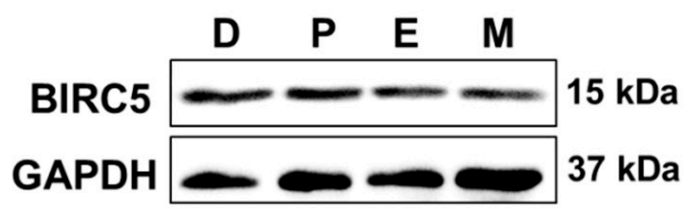

(c)

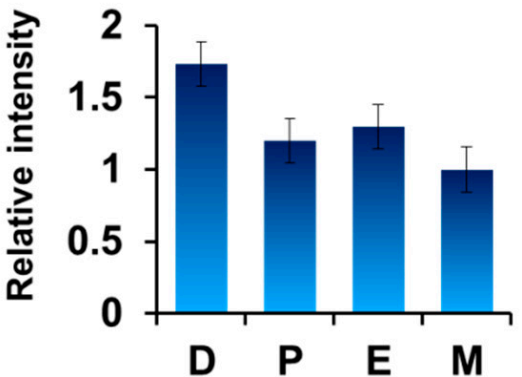

Figure 2. Expression of BIRC5 protein in mouse uterus during the estrous cycle. (a) Immunohistochemical analysis of BIRC5 in mouse uterus $(n=4)$. LE, luminal epithelium; GE, glandular epithelium; S, stroma. (b) Western blotting analysis of BIRC5 using whole cell lysate of mouse uteri from each stage of the estrous cycle $(n=4)$. GAPDH antibody (GAPDH) was used for internal control. D, diestrus; P, proestrus; E, estrus; M, metestrus. (c) Quantitation of the relative levels of BIRC5 in uterus at each stage during the estrous cycle using Image Lab program. The criterion of relative expression change was based on the value at the metestrus stage of the estrous cycle. D, diestrus; $\mathrm{P}$, proestrus; $\mathrm{E}$, estrus; $\mathrm{M}$, metestrus.

\subsection{Regulation of Birc5 Expression by Estrogen Treatment}

Previous results have indicated that Birc5 transcript and its protein were dynamically regulated during the estrous cycle of the uterus. Cyclic modulation of the normal uterine endometrium is regulated by two ovarian steroid hormones, namely, estrogen and progesterone. Therefore, we first examined the effect of estrogen $\left(\mathrm{E}_{2}\right)$ on the expression of Birc5 using ovariectomized (OVX) mice. The OVX mice were treated with $\mathrm{E}_{2}$ and their uteri were obtained at $0,3,6,12$, and $24 \mathrm{~h}$ after $\mathrm{E}_{2}$ treatment. RT-PCR analysis indicated that the expression of Birc5 mRNA gradually increased with time after $E_{2}$ administration (Figure 3a). Early growth response 1 (Egr1) and Lactoferrin (Ltf) expressions were used as referral genes marking estrogen early and late response genes, respectively (Figure $3 b$ ). The gradual induction of Birc5 expression by estrogen treatment was confirmed by semi-quantitative RT-PCR. The relative increase in Birc5 expression peaked at $24 \mathrm{~h}$ after $\mathrm{E}_{2}$ treatment (Figure $3 \mathrm{~b}$ ). Next, we examined the status of BIRC5 protein in uterine endometrium of OVX mice by immunostaining with $B I R C 5$ antibody. IHC results showed that BIRC5 protein was weakly detected without $\mathrm{E}_{2}$ treatment $(0 \mathrm{~h})$ and was heavily stained for in all layers of the uterus over time (Figure 3c). Unlike the RT-PCR results, the signal for BIRC 5 was the strongest at $6 \mathrm{~h}$ post $\mathrm{E}_{2}$ injection. This suggests that $\mathrm{E}_{2}$ promotes increase in Birc5 expression in the uterus during the estrous cycle.

\subsection{Regulation of Birc5 Expression by Progesterone Treatment}

Next, we analyzed whether progesterone $\left(\mathrm{P}_{4}\right)$ affects the expression of Birc5 in the uterus. As in the previous studies, we used ovariectomized (OVX) female mice. The OVX mice were injected with $\mathrm{P}_{4}(2 \mathrm{mg} / \mathrm{mouse})$, and the uterus samples were collected at $0,3,6$, and $24 \mathrm{~h}$. Interestingly, $\mathrm{P}_{4}$ treatment in OVX mice showed no significant effect on Birc5 expression unlike estrogen treatment. (Figure $4 a, b)$. Amphiregulin (Areg) and Homeobox A10 (Hoxa10) were used to confirm that the reaction with progesterone occurred properly (Figure 4a). qRT-PCR analysis showed that the expression level was lowest at $6 \mathrm{~h}$ after $\mathrm{P}_{4}$ treatment, but it was not a significant difference (Figure $4 \mathrm{~b}$ ). 
(a)

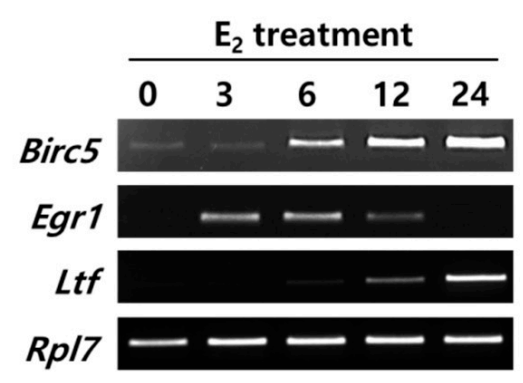

(b)

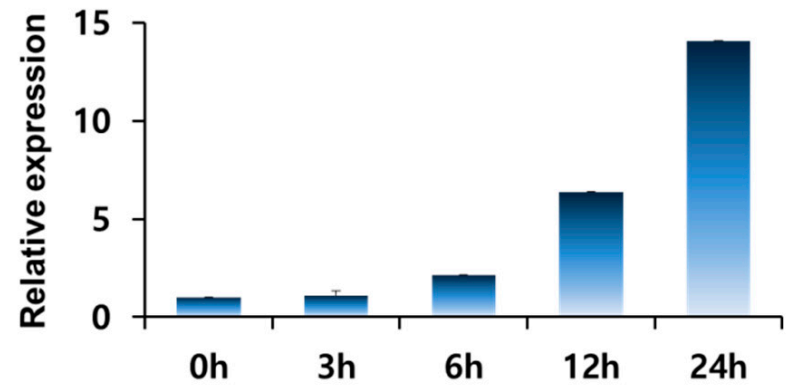

(c)

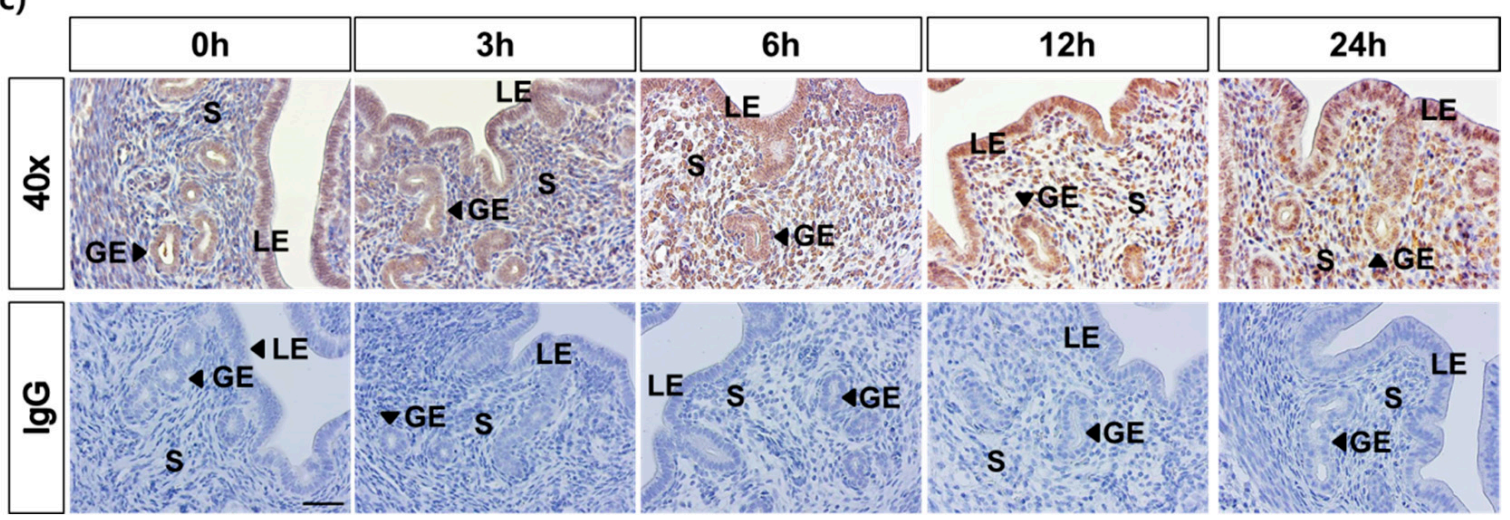

Figure 3. BIRC5 expression induced by estrogen treatment in ovariectomized (OVX) mice. (a) RT-PCR result in the uterus of the OVX mouse after $\mathrm{E}_{2}$ treatment for $0,3,6,12$, and $24 \mathrm{~h}$ (each group $n=4$ ). Early growth response 1 (Egr1) and Lactoferrin $(L t f)$ genes were used to confirm the appropriate $\mathrm{E}_{2}$ response. Ribosomal protein L7 (Rpl7) gene was used for internal control. (b) qRT-PCR analysis showed the relative fold changes in Birc5 expression caused by $\mathrm{E}_{2}$ treatment. The criterion of relative expression change was based on the value at $0 \mathrm{~h}$ after $\mathrm{E}_{2}$ treatment. (c) Localization of BIRC5 in the uterus of OVX mice treated with $E_{2}$. Normal mouse IgG was used as negative control. LE, luminal epithelium; GE, glandular epithelium; S, stroma. Scale bar, $100 \mu \mathrm{m}$.

IHC analysis also showed that BIRC5 protein was detected as basal level in the uterine endometrium of OVX mice without $\mathrm{P}_{4}$ treatment. However, its signal in the uterine endometrium of OVX mice was rapidly reduced after the administration of $\mathrm{P}_{4}$ (Figure $4 \mathrm{c}$ ). This indicates that $\mathrm{P}_{4}$ regulates the time difference in Birc5 expression in the uterus during the estrous cycle. In fact, $\mathrm{P}_{4}$ like $\mathrm{E}_{2}$, is secreted alternately from the ovary during the estrous cycle and acts jointly or solely on endometrial changes.

\subsection{Hormone-Dependent Regulation of Birc5 Expression via Hormone Receptors in the Uterus}

The expression of Birc5 rapidly responded to hormones $\mathrm{E}_{2}$ and $\mathrm{P}_{4}$ in the uterine endometrium (Figures 3 and 4). This rapid regulation of target gene expression by hormones occurs via their receptors. Therefore, we investigated whether Birc5 expression is regulated via the estrogen receptor (ER) and progesterone receptor (PR). First, an ER antagonist, ICI 182,780 (ICI), was used to determine whether ER was involved in the regulation of Birc5 expression. ICI was injected in OVX mice for $30 \mathrm{~min}$ before $\mathrm{E}_{2}$ administration. Birc5 expression was examined in the absence or the presence of $\mathrm{E}_{2}$ administration (24 h). As shown in Figure 5a, the relative expression of Birc5 mRNA was dramatically increased by $\mathrm{E}_{2}$ treatment. However, its induction was prevented with ICI pretreatment in OVX mice (Figure 5b). 
(a)

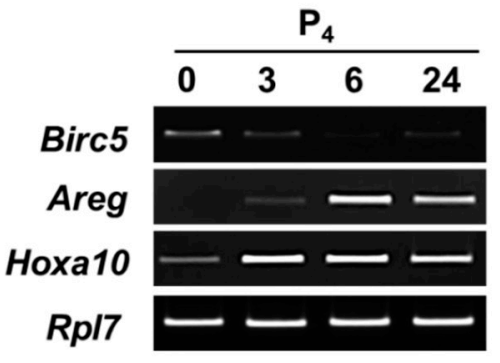

(b)

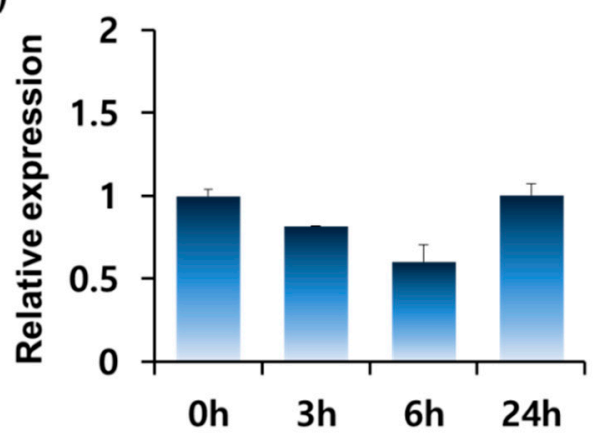

(c)

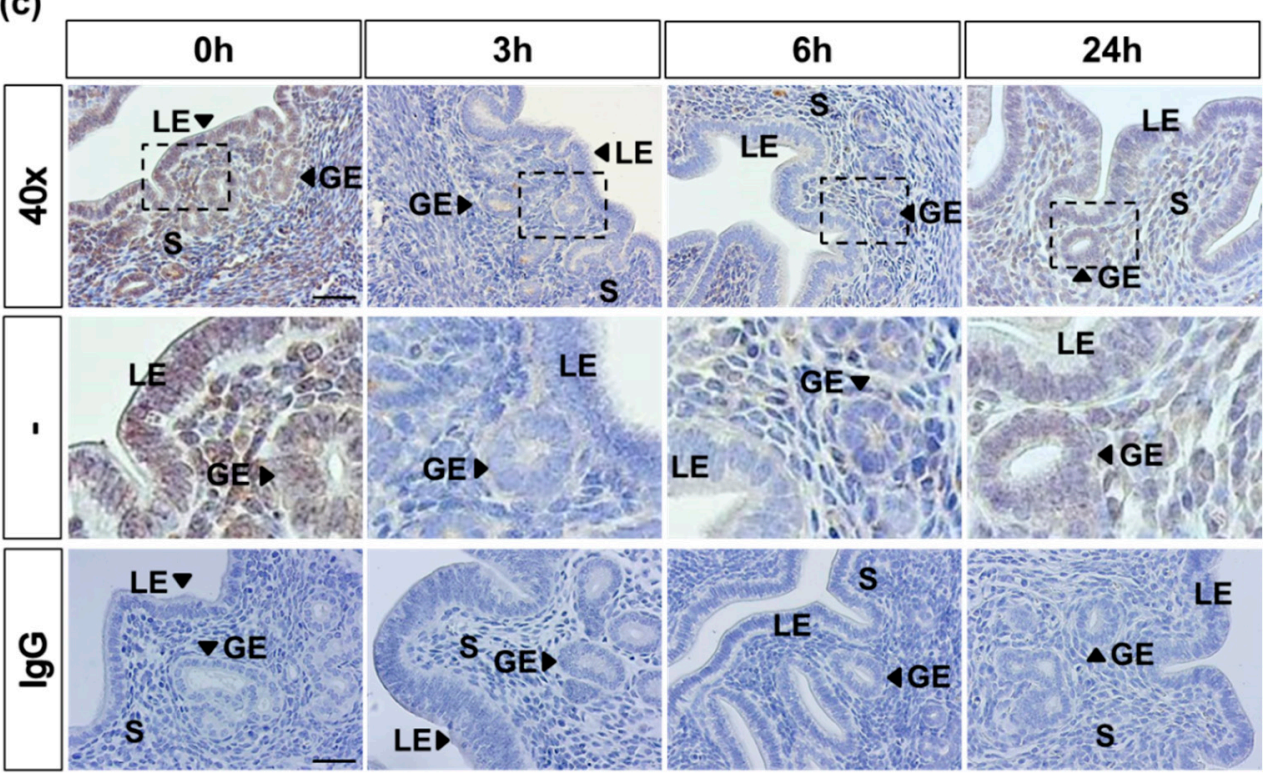

Figure 4. Reduction in Birc5 expression by progesterone in OVX mice. (a) RT-PCR analysis of Birc5 expression in the uterus of OVX mouse after $\mathrm{P}_{4}$ treatment for $0,3,6$, and $24 \mathrm{~h}$ (each group $n=4$ ). Amphiregulin (Areg) and Homeobox A10 (Hoxa10) were used to confirm the appropriate $\mathrm{P}_{4}$ response. Ribosomal protein L7 (Rpl7) gene was used as an internal control. (b) qRT-PCR result showed the relative fold changes in Birc5 expression post $\mathrm{P}_{4}$ treatment. The criterion of relative expression change was based on the value at $0 \mathrm{~h}$ after $\mathrm{E}_{2}$ treatment. (c) Immunohistochemical analysis of BIRC5 in the uterus of OVX mouse treated with $\mathrm{P}_{4}$. IgG was used as negative control. Scale bar, $100 \mu \mathrm{m}$.

Next, a PR antagonist, RU486, was used to examine whether PR was involved in the downregulation of Birc5 expression. In addition, we looked at the action of PR on ER-dependent increase in Birc5 expression in the uterus. As shown in Figure $5 c, d$, the increase in Birc 5 expression by $E_{2}$ treatment $(6 \mathrm{~h})$ was significantly reduced by co-treatment with $\mathrm{E}_{2}$ and $\mathrm{P}_{4}$ (Figure $5 \mathrm{~d}$ ). This effect of $\mathrm{P}_{4}$ on the estrogen-dependent increase was reversed by the treatment with PR antagonist, RU486 (Figure 5d). $B I R C 5$ protein was detected at higher level in $E_{2}$-treated uterine endometrium compared with the sesame oil-treated group. The effective induction by $\mathrm{E}_{2}$ was reduced by progesterone, whereas this effect was again reversed while using $\mathrm{P}_{4}$ antagonist, RU486, in the presence of estrogen in the uterine endometrium (Figure 5e). These results indicate that Birc5 expression in the uterus is precisely and dynamically regulated by $\mathrm{E}_{2}$ and $\mathrm{P}_{4}$. 
(a)

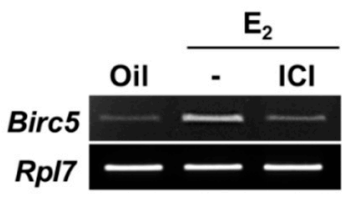

(c)

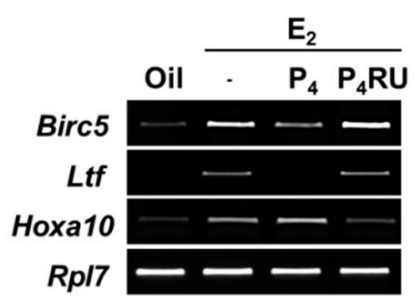

(b)

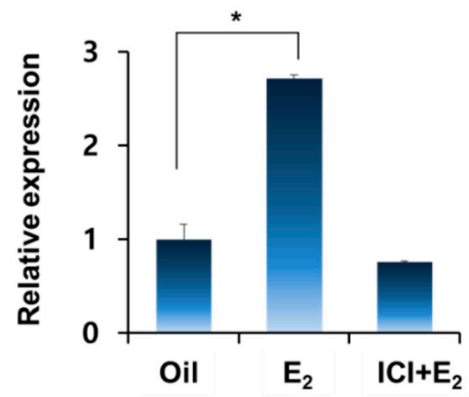

(d)

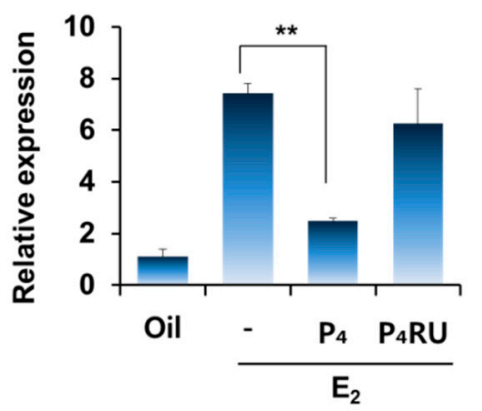

(e)

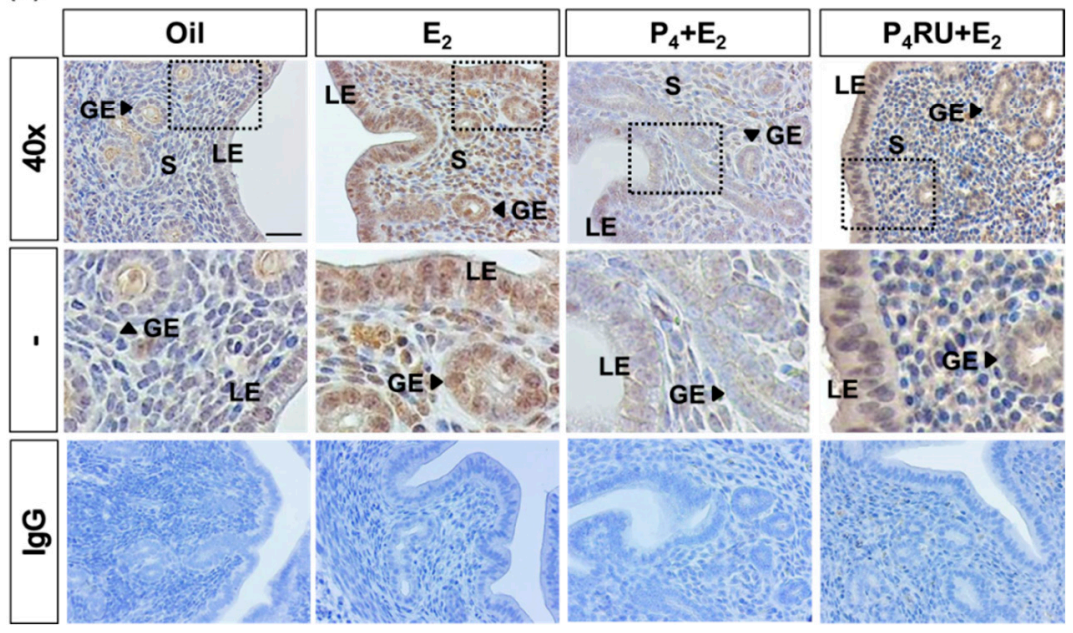

Figure 5. Regulation of Birc5 expression via estrogen and progesterone receptors. (a) Estrogen receptor (ER) antagonist, ICI 182,780 (ICI) was applied before $\mathrm{E}_{2}$ treatment and the mice were sacrificed at $24 \mathrm{~h}$ after the $E_{2}$ treatment. Birc5 expression was analyzed by RT-PCR (each group $n=4$ ). (b) qRT-PCR was used to quantify the relative level of Birc5 expression. The criterion of relative expression change was based on the value at oil treatment in OVX mice. Sesame oil, Oil; ICI 182,780 (ICI); and estrogen, $\mathrm{ICI}+\mathrm{E}_{2} \cdot{ }^{*}, p$-value $(p<0.01)$. (c) RT-PCR analysis of Birc5 expression in the uterus of OVX mice after treatment with $\mathrm{E}_{2}$ and co-treatment with $\mathrm{E}_{2}+\mathrm{P}_{4}$ or RU486 $+\mathrm{E}_{2}+\mathrm{P}_{4}$. (each group $n=4$ ). Lactoferrin $(L t f)$ and Homeobox A10 (Hoxa10) were used to confirm the appropriate hormone response. Ribosomal protein L7 ( $\mathrm{Rpl7}$ ) gene was used for internal control. (d) qRT-PCR showed the relative fold changes in Birc5 expression. The criterion of relative expression change was based on the value at oil treatment in OVX mice. ${ }^{* *}, p$-value $(p<0.01)$. (e) Immunohistochemical analysis of BIRC5 in uteri of OVX mice treated with $\mathrm{E}_{2}, \mathrm{P}_{4}+\mathrm{E}_{2}$ or RU486 $+\mathrm{E}_{2}+\mathrm{P}_{4}\left(\mathrm{P}_{4} \mathrm{RU}+\mathrm{E}_{2}\right)$.

\section{Discussion}

In this report, we presented the regulation of Birc5 expression in the uterus. We found that Birc5 is periodically expressed in the uterus during the estrous cycle (Figures 1 and 2). Moreover, we showed that its cyclic expression is related to two ovarian hormones, namely, estrogen and progesterone 
(Figures 3 and 4). Interestingly, we demonstrated that estrogen positively regulates Birc5 expression through its receptor in the uterine epithelium (Figure 5). This needs further study to prove the involvement in Birc5 expression. This implies that Birc5 plays a role in the uterine dynamics during the estrous cycle in normal status.

As a member of the IAP family, Birc5 is expressed in various cells including hematopoietic cells, immune cells and vascular endothelial cells, and mesenchymal stromal cells $[4,17,18]$. Additionally, Birc5 plays a role in regulating cell proliferation and survival. One of its functions is to inhibit apoptosis by acting on caspases in the cytoplasm and mitochondria. Further, Birc5 is also located in the nucleus and regulates cell cycle factors [29,30].

The uterus, which is composed of endometrium and myometrium, is a part of the female reproductive system. The uterine endometrium consists of a single columnal epithelium and a connective tissue stromal layer. The uterine layers are cyclically changed with periodic proliferation, differentiation, and apoptosis. This cycle is called the estrous cycle in the rodents. The remodeling of the uterus is controlled by female sex steroid hormones such as estrogen $\left(E_{2}\right)$ and progesterone $\left(P_{4}\right)$. Therefore, we investigated the relationship between Birc5 expression and uterine endometrium.

Nabilsi et al. have reported the relationship between BIRC5 and sex hormones in the human uterus [31]. They analyzed the expression of BIRC5 in proliferative and secretory phases of normal menstrual cycle and found that BIRC5 expression was higher in the proliferative phase than in the secretory phase. They further observed that BIRC5 expression was increased in the human endometrium after estrogen treatment, which then decreased upon progestin treatment [31]. It was the first evidence showing that BIRC5 expression is regulated by female sex hormones. However, it remained unclear whether the hormones acted alone or together.

In fact, although progesterone and estrogen secretion stages are different, they are organically associated rather than acting separately. Skinner et al. reported that progesterone is critical for the full effect of estrogen in ewes [32]. Therefore, we used the OVX model to show their individual effect on BIRC5 expression in the uterus. Each treatment on OVX mice showed a similar pattern as that observed in the study by Nabilsi and colleague. Birc5 transcripts were increased with $\mathrm{E}_{2}$ administration into OVX mice and this increase was significantly reduced by pretreatment with ER antagonist ICI 182,780. This suggests that Birc5 is regulated in the uterine epithelium via estrogen receptor-associated hormonal signaling. It has been shown that Birc5 is regulated by various signaling pathways such as PI3K/Akt, mTOR, ERK, and NFkB pathways [33,34]. Interestingly, the increased expression of Birc5 was decreased by $\mathrm{P}_{4}$ administration. This suggests that Birc5 is regulated by both $\mathrm{E}_{2}$ and $\mathrm{P}_{4}$, during the dynamic uterine cycle.

In conclusion, the present study demonstrated that Birc5 may be periodically regulated by estrogen and progesterone in the endometrium of the uterus during the estrous cycle. This finding provides insights into understanding the regulatory mechanism underlying the endometrial dynamics.

Supplementary Materials: The following are available online at http://www.mdpi.com/2073-4425/11/3/282/s1, Table S1: PCR conditions and size of gene-specific primers.

Author Contributions: Conceptualization, Y.C. and O.-H.L.; Methodology, M.C., S.L.; Validation, M.C., E.M.C., and O.-H.L.; Formal analysis, M.C., E.M.C., and O.-H.L.; Investigation, M.C., E.M.C., and O.-H.L.; Resources, S.M., J.L., C.P., K.H., K.-H.P. and H.P.; Data curation, M.C., E.M.C., and O.-H.L.; Writing-original draft preparation, M.C. and Y.C.; Writing-review and editing, E.M.C. and O.-H.L.; Visualization, S.M., J.L., and H.P.; Supervision, O.-H.L. and Y.C.; Project administration, Y.C.; Funding acquisition, Y.C., K.-H.P., O.-H.L. and E.M.C. All authors have read and agreed to the published version of the manuscript.

Funding: This research was supported by grants awarded by Basic Science Research Program through National Research Foundation of Korea funded by the Ministry of Education (2017R1A1A1A05001385, 2018R1D1A1B07050290 and 2019R1A6A1A03032888) and a grant from National Research Foundation of The Ministry of Science, ICT \& Future Planning (2015R1A5A1009701).

Acknowledgments: This research was supported by a grant awarded by Basic Science Research Program through National Research Foundation of Korea funded by the Ministry of Education (2017R1A1A1A05001385, 2018R1D1A1B07050290 and 2019R1A6A1A03032888) and a grant from National Research Foundation of The Ministry of Science, ICT \& Future Planning (2015R1A5A1009701). 
Conflicts of Interest: The authors declare no conflict of interest.

$\begin{array}{ll}\text { Abbreviations } \\ \mathrm{D} & \text { Diestrus } \\ \mathrm{P} & \text { Proestrus } \\ \mathrm{E} & \text { Estrus } \\ \mathrm{M} & \text { Metestrus } \\ \mathrm{LE} & \text { Luminal epithelium } \\ \mathrm{GE} & \text { Glandular epithelium } \\ \mathrm{S} & \text { Stroma } \\ \mathrm{IHC} & \text { Immunohistochemistry } \\ \mathrm{E}_{2} & \text { Estrogen } \\ \mathrm{P}_{4} & \text { Progesterone } \\ \mathrm{ER} & \text { Estrogen receptor } \\ \mathrm{ICI} & \text { ICI 182,780 } \\ \mathrm{PR} & \text { Progesterone receptor }\end{array}$

\section{References}

1. Konno, R.; Yamakawa, H.; Utsunomiya, H.; Ito, K.; Sato, S.; Yajima, A. Expression of survivin and Bcl-2 in the normal human endometrium. Mol. Hum. Reprod. 2000, 6, 529-534. [CrossRef] [PubMed]

2. Hong, K.; Choi, Y. Role of estrogen and RAS signaling in repeated implantation failure. BMB Rep. 2018, 51, 225-229. [CrossRef] [PubMed]

3. Ambrosini, G.; Adida, C.; Altieri, D.C. A novel anti-apoptosis gene, survivin, expressed in cancer and lymphoma. Nat. Med. 1997, 3, 917-921. [CrossRef] [PubMed]

4. Fukuda, S.; Pelus, L.M. Survivin, a cancer target with an emerging role in normal adult tissues. Mol. Cancer Ther. 2006, 5, 1087-1098. [CrossRef] [PubMed]

5. Tamm, I.; Wang, Y.; Sausville, E.; Scudiero, D.A.; Vigna, N.; Oltersdorf, T.; Reed, J.C. IAP-family protein survivin inhibits caspase activity and apoptosis induced by Fas (CD95), Bax, caspases, and anticancer drugs. Cancer Res. 1998, 58, 5315-5320.

6. Deguchi, M.; Shiraki, K.; Inoue, H.; Okano, H.; Ito, T.; Yamanaka, T.; Sugimoto, K.; Sakai, T.; Ohmori, S.; Murata, K.; et al. Expression of survivin during liver regeneration. Biochem. Biophys. Res. Commun. 2002, 297, 59-64. [CrossRef]

7. Blanc-Brude, O.P.; Yu, J.; Simosa, H.; Conte, M.S.; Sessa, W.C.; Altieri, D.C. Inhibitor of apoptosis protein survivin regulates vascular injury. Nat. Med. 2002, 8, 987-994. [CrossRef]

8. Chiou, S.K.; Moon, W.S.; Jones, M.K.; Tarnawski, A.S. Survivin expression in the stomach: Implications for mucosal integrity and protection. Biochem. Biophys. Res. Commun. 2003, 305, 374-379. [CrossRef]

9. Jiang, Y.; de Bruin, A.; Caldas, H.; Fangusaro, J.; Hayes, J.; Conway, E.M.; Robinson, M.L.; Altura, R.A. Essential role for survivin in early brain development. J. Neurosci. 2005, 25, 6962-6970. [CrossRef]

10. Kumazawa, Y.; Kawamura, K.; Sato, T.; Sato, N.; Konishi, Y.; Shimizu, Y.; Fukuda, J.; Kodama, H.; Tanaka, T. HCG up-regulates survivin mRNA in human granulosa cells. Mol. Hum. Reprod. 2005, 11, 161-166. [CrossRef]

11. Kobayashi, K.; Hatano, M.; Otaki, M.; Ogasawara, T.; Tokuhisa, T. Expression of a murine homologue of the inhibitor of apoptosis protein is related to cell proliferation. Proc. Natl. Acad. Sci. USA 1999, 96, 1457-1462. [CrossRef] [PubMed]

12. Wang, Y.; Suominen, J.S.; Hakovirta, H.; Parvinen, M.; Martinand-Mari, C.; Toppari, J.; Robbins, I. Survivin expression in rat testis is upregulated by stem-cell factor. Mol. Cell. Endocrinol. 2004, 218, 165-174. [CrossRef] [PubMed]

13. Weikert, S.; Schrader, M.; Krause, H.; Schulze, W.; Muller, M.; Miller, K. The inhibitor of apoptosis (IAP) survivin is expressed in human testicular germ cell tumors and normal testes. Cancer Lett. 2005, 223, 331-337. [CrossRef] [PubMed] 
14. Uren, A.G.; Wong, L.; Pakusch, M.; Fowler, K.J.; Burrows, F.J.; Vaux, D.L.; Choo, K.H. Survivin and the inner centromere protein INCENP show similar cell-cycle localization and gene knockout phenotype. Curr. Biol. 2000, 10, 1319-1328. [CrossRef]

15. Okada, H.; Bakal, C.; Shahinian, A.; Elia, A.; Wakeham, A.; Suh, W.K.; Duncan, G.S.; Ciofani, M.; Rottapel, R.; Zuniga-Pflucker, J.C.; et al. Survivin loss in thymocytes triggers p53-mediated growth arrest and p53-independent cell death. J. Exp. Med. 2004, 199, 399-410. [CrossRef] [PubMed]

16. Xing, Z.; Conway, E.M.; Kang, C.; Winoto, A. Essential role of survivin, an inhibitor of apoptosis protein, in T cell development, maturation, and homeostasis. J. Exp. Med. 2004, 199, 69-80. [CrossRef]

17. Fukuda, S.; Hoggatt, J.; Singh, P.; Abe, M.; Speth, J.M.; Hu, P.; Conway, E.M.; Nucifora, G.; Yamaguchi, S.; Pelus, L.M. Survivin modulates genes with divergent molecular functions and regulates proliferation of hematopoietic stem cells through Evi-1. Leukemia 2015, 29, 433-440. [CrossRef]

18. Singh, P.; Fukuda, S.; Liu, L.; Chitteti, B.R.; Pelus, L.M. Survivin Is Required for Mouse and Human Bone Marrow Mesenchymal Stromal Cell Function. Stem Cells 2018, 36, 123-129. [CrossRef]

19. Mirza, A.; McGuirk, M.; Hockenberry, T.N.; Wu, Q.; Ashar, H.; Black, S.; Wen, S.F.; Wang, L.; Kirschmeier, P.; Bishop, W.R.; et al. Human survivin is negatively regulated by wild-type p53 and participates in p53-dependent apoptotic pathway. Oncogene 2002, 21, 2613-2622. [CrossRef]

20. Guha, M.; Plescia, J.; Leav, I.; Li, J.; Languino, L.R.; Altieri, D.C. Endogenous tumor suppression mediated by PTEN involves survivin gene silencing. Cancer Res. 2009, 69, 4954-4958. [CrossRef]

21. Wang, R.H.; Zheng, Y.; Kim, H.S.; Xu, X.; Cao, L.; Luhasen, T.; Lee, M.H.; Xiao, C.; Vassilopoulos, A.; Chen, W.; et al. Interplay among BRCA1, SIRT1, and Survivin during BRCA1-associated tumorigenesis. Mol. Cell 2008, 32, 11-20. [CrossRef] [PubMed]

22. Huang, W.T.; Tsai, Y.H.; Chen, S.H.; Kuo, C.W.; Kuo, Y.L.; Lee, K.T.; Chen, W.C.; Wu, P.C.; Chuang, C.Y.; Cheng, S.M.; et al. HDAC2 and HDAC5 Up-Regulations Modulate Survivin and miR-125a-5p Expressions and Promote Hormone Therapy Resistance in Estrogen Receptor Positive Breast Cancer Cells. Front. Pharmacol. 2017, 8, 902. [CrossRef] [PubMed]

23. Chen, X.; Zhang, Z.; Feng, Y.; Fadare, O.; Wang, J.; Ai, Z.; Jin, H.; Gu, C.; Zheng, W. Aberrant survivin expression in endometrial hyperplasia: Another mechanism of progestin resistance. Mod. Pathol. 2009, 22, 699-708. [CrossRef] [PubMed]

24. Bae, S.; Kwon, H.; Yoon, H.; Park, M.; Kim, H.R.; Song, H.; Hong, K.; Choi, Y. Estrogen-dependent expression of sine oculis homeobox 1 in the mouse uterus during the estrous cycle. Biochem. Biophys. Res. Commun. 2016, 472, 489-495. [CrossRef]

25. Jeong, J.H.; Park, M.; Park, M.; Lim, E.J.; Kim, H.R.; Song, H.; Park, S.G.; Choi, E.J.; Hong, K.H.; Lee, D.R.; et al. The expression of aminoacyl-tRNA-synthetase-interacting multifunctional protein-1 (Aimp1) is regulated by estrogen in the mouse uterus. Mol. Cell. Endocrinol. 2015, 399, 78-86. [CrossRef]

26. Kim, H.R.; Cho, K.S.; Kim, E.; Lee, O.H.; Yoon, H.; Lee, S.; Moon, S.; Park, M.; Hong, K.; Na, Y.; et al. Rapid expression of RASD1 is regulated by estrogen receptor-dependent intracellular signaling pathway in the mouse uterus. Mol. Cell. Endocrinol. 2017, 446, 32-39. [CrossRef]

27. Evans, H.M.; Long, J.A. Characteristic effects upon growth, oestrus and ovulation induced by the intraperitoneal administration of fresh anterior hypophyseal substance. Proc. Natl. Acad. Sci. USA 1922, 8, 38-39. [CrossRef]

28. Livak, K.J.; Schmittgen, T.D. Analysis of relative gene expression data using real-time quantitative PCR and the 2- $\Delta \Delta$ CT method. Methods 2001, 25, 402-408. [CrossRef]

29. Lens, S.M.; Vader, G.; Medema, R.H. The case for Survivin as mitotic regulator. Curr. Opin. Cell Biol. 2006, 18, 616-622. [CrossRef]

30. Garg, H.; Suri, P.; Gupta, J.C.; Talwar, G.P.; Dubey, S. Survivin: A unique target for tumor therapy. Cancer Cell Int. 2016, 16, 49. [CrossRef]

31. Nabilsi, N.H.; Broaddus, R.R.; McCampbell, A.S.; Lu, K.H.; Lynch, H.T.; Chen, L.M.; Loose, D.S. Sex hormone regulation of survivin gene expression. J. Endocrinol. 2010, 207, 237-243. [CrossRef] [PubMed]

32. Caraty, A.; Skinner, D.C. Progesterone priming is essential for the full expression of the positive feedback effect of estradiol in inducing the preovulatory gonadotropin-releasing hormone surge in the ewe. Endocrinology 1999, 140, 165-170. [CrossRef] [PubMed] 
33. Su, J.C.; Lin, K.L.; Chien, C.M.; Tseng, C.H.; Chen, Y.L.; Chang, L.S.; Lin, S.R. Naphtho[1,2-b]furan-4,5-dione inactivates EGFR and PI3K/Akt signaling pathways in human lung adenocarcinoma A549 cells. Life Sci. 2010, 86, 207-213. [CrossRef] [PubMed]

34. Kanwar, J.R.; Kamalapuram, S.K.; Kanwar, R.K. Targeting survivin in cancer: The cell-signalling perspective. Drug Discov. Today 2011, 16, 485-494. [CrossRef] 